\section{Task-based Activities in TEFL}

\section{Fachrurrazy}

Universitas Negeri Malang

Abstract: This article presents a discussion of task-based approach in Communicative Language Teaching. A task is a classroom activity involving learner's interaction in which the main attention is on the meaning more than on the form of the target language. This approach may be applicable to TEFL in Indonesian context.

Key words: task-based approach

This article constitutes a discussion of a trend in Communicative Language Teaching (CLT), that is the task-based approach. This approach, which emphasises a focus on meaning in language learning, emerged in the 1980 s. The discussion is focused on the background of the emergence of taskbased approach, its characteristics and components, and the possibility of its application for TEFL in Indonesia.

\section{BACKGROUND OF TASK-BASED APPROACH}

Since its emergence in the 1970s Communicative Language Teaching (CLT) has undergone three phases (Rodgers, 1990:6-7), namely, the Wilkins Period with the terms of notions and functions, the Munby Period with the needs analysis, and the Prabhu Period with the procedural, process, and task syllabus. Wilkins' idea and other notional-functional syllabuses were criticised as merely replacing one kind of list such as a list of grammar items (in structural syllabus) with another, i.e. a list of notions and functions, and therefore lacking a communicative process (Richards and Rodgers, 1986:74). They are referred to as type A or synthetic syllabuses. A synthetic syllabus is one in which elements of the target language are separated into pieces and taught step by step; and then, it is the learners' tasks to synthesise the pieces when they want to use them for communication (Long and Crookes, 1992:28). Munby's idea appears to have developed into English for specific purposes (ESP). The Prabhu Period is characterised by the development of task-based CLT. Prabhu introduced one type of task-based CLT, called the procedural syllabus, which was trialled in Bangalore/Madras Communicational Teaching Project (Beretta and Davies, 1985; Long and Crookes, 1992:34).

In addition to the procedural syllabus, Long and Crookes (1992) identify two other types of task-based CLT, namely, the process syllabus (Breen, 1984; Candlin, 1987; Candlin and Murphy, 1987) and the task syllabus (Long and Crookes, 1992; Nunan, 1991). These three syllabuses, which are referred to as type B syllabuses, or analytic syllabuses, reject linguistic elements (such as word, structure, notion, or function) as the unit of syllabus design, and instead adopt a conception of task as an alternative.

\section{CHARACTERISTICS OF TASK-BASED ACTIVITIES}

The three types of task-based syllabus stated above have slight differences. The procedural syllabus, for instance, rejects a focus on form in its instruction (Prabhu, 1984:275-276), meaning that there is no grammar lesson for learners. Compared with the procedural syllabus, the process syllabus is more learner-centred. Long and Crookes (1992:38) explain that the proponents of the process syllabus maintain that "any syllabus, preset or not, is constantly subject to negotiation and reinterpretation by teachers and learners in the classroom." In its implementation, the process syllabus is criticised since it implies a change of role relationships and a redistribution of power and authority in the classroom that would be too radical and/or culturally unacceptable in some societies (Long and Crookes, 1992:39).

The third type of task-based CLT, which is the task syllabus or taskbased language teaching (TBLT), seems to be more promising for its application in Indonesian context, especially because it does not exclude focus on form and does not suggest a radical change of relationship between teach- 
ers and learners. Long and Crookes (1992) mention that task-based language teaching integrates meaning-focused and form-focused tasks. As stated by Savignon (1991:269), "for the development of communicative ability, research findings overwhelmingly support the integration of form-focused exercises with meaning-focused experience." Meaning-focused tasks are based on a premise that language mastery is best acquired through negotiation of meaning in the process of interaction, and form-focused tasks are based on a premise that language mastery is best acquired when language form is brought to the attention of the learner during the negotiation of meaning. The focus on form in TBLT, however, does not imply a return of the grammar-based or synthetic syllabus. The focus on form here (Long and Crookes, 1992) refers to the use of pedagogic tasks which draw students' attention to the features of the target language itself. The trigger for this is the teacher's noticing of errors which are systematic, pervasive, and remediable in the students (Long, 1991:45-46).

Tasks in TBLT are categorised into target tasks, task types, pedagogic tasks, and task syllabus. Target tasks are defined (Long, 1990:35) as "the things the learners will eventually do in English, at school or university, at work, in a vocational training program, on vacation, and so on-a nontechnical, non-linguistic definition." The selection of tasks is based on the learner's real or potential needs in the world beyond the classroom and also with reference to theoretical and empirical insights into those social and psycholinguistic processes which facilitate language acquisition (Nunan, 1991:279). After the selection of target tasks, the next step is to classify them into task types. For example, "serving food and beverages" in a training course for flight attendants may be a task type which comprises the tasks of serving breakfast, lunch, dinner, and snacks and refreshments (Long and Crookes, 1992:44). Pedagogic tasks are derived from task types and are sequenced to form a task syllabus. According to Long (1990:35), pedagogic tasks are activities which are conducted by teachers and students in the classroom. Another pedagogically oriented definition of task is suggested by Richards, Platt, and Weber (1985:289), namely:

an activity or action which is carried out as the result of processing or understanding language (i.e. as a response). For example, drawing a map while listening to a tape, listening to an instruction and performing a command, may be referred to as tasks. Tasks may or may not involve the production of language. A task usually requires the teacher to specify what will be regarded as successful completion of the task.

As proposed by Nunan (1991:279), the task-based CLT has the following features:

1. An emphasis on learning to communicate through interaction in the target language

2. The introduction of authentic texts into the learning situation

3. The provision of opportunities for learners to focus, not only on language, but also on the learning process itself

4. An enhancement of the learners' own personal experiences as important contributing elements to classroom learning

5. An attempt to link classroom language leaming with language activation outside the classroom

Long and Crookes (1992:43) emphasise that tasks are activities which focus on something that is done, not something that is said. Pica, Kanagy, and Falodun (1993:18-23) discuss five task types which have been used by researchers, namely: (1) jigsaw (e.g. Gass and Varonis, 1985); (2) information gap (e.g. Pica, Young, and Doughty, 1987); (3) problem-solving (e.g. Crookes and Rulon, 1985); (4) decision-making (e.g. Duff, 1986); and (5) opinion exchange (e.g. Pica, et al. 1990). Jigsaw tasks are characterised by activities of exchanging and manipulating different information possessed by different participants. In information gap tasks, one participant possesses information which other participants need to complete their tasks. Problem-solving tasks are interaction activities which are oriented toward one resolution of outcome. Decision-making tasks refer to participants' activities in selecting one out of a number of available outcomes. Finally, opinion exchange tasks require participants to engage in discussion and exchange of ideas.

Research has been conducted into the effectiveness of interactions using these various pedagogic tasks (jigsaw, information gap, problem solving, decision making, or opinion exchange) (Pica, Kanagy, and Falodun, 
1993:19). Long (1981), for instance, investigated one-way tasks versus twoway tasks. He found that two-way tasks, in which all students in a group discussion had unique information to contribute, stimulated significantly more modified interactions than one-way tasks, in which one member of the group possessed all the relevant information. Doughty and Pica (1986) studied required information-exchange tasks versus tasks in which the exchange of information was optional. They found that the former tasks generated significantly more modified interaction than the latter tasks. Berwick (1988, as cited in Nunan, 1991) investigated the different types of language stimulated by transactional tasks, in which communication occurs principally to bring about the exchange of goods and services, and interpersonal tasks, in which communication occurs largely for social purposes. Berwick found that the different functional purposes stimulated different realisation of grammatical categories. Long, et al. (1976) found that small-group tasks prompt students to use a greater range of language functions than teacherdominated tasks. Nunan (1991) investigated the different interactional patterns stimulated by open tasks, in which there is no single correct answer, and closed tasks, in which there is a single correct answer or a restricted number of correct answers. He found that closed tasks stimulated more modified interactions with lower-intermediate to intermediate learners. As concluded by Nunan (1991), some task types might be more appropriate for particular learners than others.

\section{COMPONENTS AND SAMPLE OF TASK}

A task consists of several components. Wright (1987) states that a task should minimally contain two elements, namely, input data and an initiating question for learners to work on. Candlin (1987) suggests that a task should contain input, roles, settings, actions, monitoring, outcomes, and feedback. Nunan (1989:47-95) proposes six components of a task, namely: goals, input, activities, teacher role, learner role, and settings.

Goals are described as what is intended to be achieved through a learning task. They are not necessarily stated explicitly since they can be inferred from the task. Clark (in Nunan, 1991:49) proposes four goal types.
They are: (1) communicative goals, which refer to the establishment and maintenance of interpersonal relationship through which exchange of information, ideas, opinions, attitudes, and feelings occurs, or things can be done; (2) socio-cultural goals, namely an understanding of daily life patterns of the target language community; (3) learning-how-to-learn goals, which are an ability to plan work and find ways to attain its objective; and (4) language and cultural awareness goals, i.e. an understanding of the system of the target language and how it works.

Input refers to the data, such as picture stories, photographs, drawings, shopping lists, brochures, street map, recipe, newspaper extracts, editorials, or postcards, which are used as the point of departure for doing the task.

Activities are what learners will do with the input. Nunan (1991:59) proposes three characteristics of task activities, namely, "rehearsal for the real world; skill use; and fluency/accuracy." The types of activity (i.e. jigsaw, information gap, problem solving, decision making, and opinion exchange) have been discussed in the task types above.

Teacher role and learner role specify the parts which teacher and learner will play respectively. In using tasks, a teacher is expected to assume two roles (Breen and Candlin, 1980:99):

The first role is to facilitate the communication process between all participants in the classroom, and between these participants and the various activities and texts. The second role is to act as an independent participant within the learning-teaching group.

Settings are the classroom arrangements specified for a task. Task activities can be carried out partly or wholly in the classroom or outside the classroom. They may involve whole class, small groups, pairs, or individuals.

These six components are an elaboration of Nunan's (1989:47) four core components of a task, namely, "the goals, the input (linguistic or otherwise), the activities derived from this input, and finally the roles implied for teacher and learners." 
The following is an example of task-based activities for elementary school students. The task is prepared to include the four core components stated above (i.e. goals, input, activities, and roles for teacher and learners) These components are incorporated in a format which consists of preparation, i.e. the teaching content and media to be prepared before the implementation of a lesson in class, and procedure, i.e. teaching and learning activities and their sequence to be carried out in class.

\section{Fruits Preference}

\section{Preparation:}

1. Prepare a chart of fruits (apple, orange, banana, mango, pineapple, water melon, jack-fruit, rambutan, grapes) with labels.

2. Draw four pictures on carton paper, each about: (1) Ali and his house, (2) a kitchen with a fridge, (3) an open fridge with some kinds of fruits in it, (4) Ali, holding some fruits.

3. Prepare a number or fruits (realia).

\section{Procedure:}

1. a. Put pictures 1-4 on board and write under each picture:

1) This is Ali. This is Ali's house.

2) There is a kitchen in Ali's house.

There is a fridge in the kitchen.

3) There are some fruits in the fridge:

apples, bananas, durians, grapes, mangoes,

oranges, papayas, rambutans, watermelons.

4) Ali likes apples, bananas, and rambutans.

b. Read the text by pointing to the pictures, and let the students listen.

2. a. Then, offer fruits (realia) to 5 students in turns by saying: Do you like apple?

(banana, mango, etc.), and give it to the student if the response is Yes. b. (To the 5 students): Hold your fruits. (Then, to other students):

1) Stand up, please.

2) Point to the apple.

3) Point to the banana (mango, grapes, etc.)

4) (For fun) Point to your friend (the door, the window)

5) Sit down, please.

3. a. Put a fruit chart on board and say: Here are some fruits for you. Which fruits do you like? Ask several students in turn to write on the board, 3 fruits they like and 3 fruits they do not like. As an aid for the students, write on board: I like I don't like

b. Ask all students to write what they like and what they do not like in their notebooks.

c. Divide class into 3 groups, and ask one student for each group to count the number of students who like certain fruit.

d. Write the fruits and the numbers on board.

e. Discuss the favourite fruits by counting the total numbers of fruits selected by students.

4. Ask students to draw and colour one of their favourite fruits in their notebooks.

5. Assign students to ask their parents' favourite fruits.

This task activity was used in the first term of grade three students (beginners in English) of an elementary school in Mailang.

\section{TBLT APPROACH FOR TEFL IN INDONESIA}

As discussed above, TBLT is the current trend in CLT. It is characterised by the use of tasks in teaching and learning process. Given that TBLT integrates meaning-focused and form-focused instructions, and it is an effective approach for increasing student interactions, it may be worth considering for its application in primary and secondary schools in Indonesia. As a new approach for teachers in Indonesia, there are some recom- 
mendations relating to the current syllabus and textbooks, demand of evaluation system, teacher's belief, and use of the target language.

Firstly, the current syllabus (i.e. the 1994 English syllabus) and the available textbooks have not been designed using the task-based approach. However, since the task-based approach is concerned with teaching and However, since the task-based approach is concerned with teaching and preparations to adopt the task-based approach.

Secondly, the application of task-based approach will face a problem with the demand of the evaluation system (EBTA). Since the emphasis of the assessment using task-based approach is on what the students do rather than on what they say, it does not match with the demand of the current evaluation system which is focused on language accuracy. For the time being teachers are advised to apply the approach gradually, and combine it with the teaching and learning activities based on the demand of the evaluation system. At the elementary school level, however, the approach can be fully implemented because English is a local content subject and so the student assessment is determined by the EFL teachers themselves, not by the external examination.

Thirdly, the EFL teachers in Indonesia may have their own belief for their teaching practices. The teachers' belief may be in the form of their perception that they are "not teaching" if they do not teach grammar in their traditional ways (e.g. grammar explanation and mechanical drills). In the long run, such a belief needs to be revised. Approaches, methods, and techniques for TEFL develop, and teachers need to develop and keep up with teaching-learning developments.

Fourthly, for the use of the target language, two things need to be considered. On the one hand, there is a challenge for teachers to improve their mastery of English to meet the demand of the use of the target language in teaching. On the other hand, beginning EFL learners may encounter difficulties when the teacher uses English only (the target language) in the classroom. To overcome the learners' difficulties due to their limited language mastery, Prabhu (1984:278-279) suggests that other communicative resources such as guessing, gestures, native language, or actions be used. The use of native language in a foreign language situation may be an option.
It may be used when there are certain distinct advantages for students" comprehension and class management. Native language may be used only for short stretches of time. Examples of such advantages (Brown, 1994:105) include:

- negotiation of disciplinary and other management factors

- brief descriptions of how to carry out a technique

- brief explanations of grammar points

- quick pointers on meanings of words that remain confusing after students have had a try at defining something themselves

- cultural notes and comments

In using actions as an aid for learners' comprehension, the Total Physical Response (TPR) approach can be considered. TPR approach is characterised by a large number of activities in listening and acting, directed by the teacher (Brown, 1994:64). Using TPR, learners can learn a new language without worrying about mistakes they might make in their first efforts to use the language (Lightbown and Spada, 1993:90).

\section{CONCLUDING REMARK}

As a concluding remark, the task-based approach implies the use of the principle of student-active leaming approach and an emphasis on interaction in learning a language. In consequence of the adoption of studentactive learning approach in primary and secondary school curriculum in Indonesia, teachers should think of the benefit for their students, and not merely of their comfort in teaching practices.

In the writer's experience in using task-based activities at the primary school level, the class situation changed. The students were seen enthusiastic in doing the activities. They sometimes became noisy because they shouted or yelled when they succeeded in doing a task or when they gave support to their friends who were doing certain tasks. In addition, the involvement of physical activities caused the students not to sit still in their seats. They often stood or moved around. Students' noise and movement should be tolerated because these were the ways to let students interact as suggested in language learning process using tasks. 


\section{REFERENCES}

Beretta, A. and Davies, A. 1985. Evaluation of the Bangalore Project. ELT Journal, $39(2): 121-127$

Breen, M.P. 1984. Process Syllabuses for the Language Classroom. In Brumfit, C.J. (Ed.), General English Syllabus Design (ELT Document) 118:47-60 London: Pergamon and The British Council.

Breen, M.P. and Candlin, C.N. 1980. The Essentials of a Communicative Curriculum in Language Teaching. Applied Linguistics, 1(2):89-112.

Grown, HD 1994 Teaching by Principles: An Interactive Approach to Language Pedagogy. Englewood Cliffs, N.J.: Prentice Hall Regents.

Candlin, C.N. 1987. Towards Task-based Language Learning. In Candlin, C.N. and Murphy, D. (Eds.), Language Learning Tasks (Lancaster Practical Papers in English Language Education) 7: 5-22. Englewood Ciiffs, N.J.: Prentice Hall. Candlin, C.N. and Murphy, D. (Eds.). 1987. Language Learning Tasks (Lancaster Practical Papers in English Language Education, Volume 7). Englewood Cliffs, N.J.: Prentice Hall.

Crookes, G. and Rulon, K. 1985. Incorporation of Corrective Feedback in Native Speaker/Non-native Speaker Conversation (Technical Report No. 3). Manoa: The Center for Second Language Classroom Research, Social Science Research Institute, University of Hawaii at Manoa.

Doughty, C. and Pica, T. 1986. "Information Gap" Tasks: Do They Facilitate Second Language Acquisition? TESOL Quarterly, 20(3):305-325.

Duff, P. 1986. Another Look at Interlanguage Talk: Taking Task to Task. In Day, R R (Ed), Talking to Learn: Conversation in Second Language Acquisition. Rowley, Mass.: Newbury House.

Gass, S.M. and Varonis, E. 1985. Task Variation and NNS/NNS Negotiation of Meaning. In Gass, S.M. and Madden, C. (Eds.), Input in Second Language Acquisition. Rowley, Mass.: Newbury House.

Lightbown, P. and Spada, N. 1993. How Languages are Learned. Oxford: OUP.

Long, M.H. 1981. Input, Interaction and Second Language Acquisition. In Winitz, H. (Ed.), Native Language and Foreign Language Acquisition. New York: New York Academy of Sciences.

Long, M.H. 1990. Task, Group, and Task-group Interactions. In Anivan, S. (Ed.), Language Teaching Methodology for the Nineties, Anthology Series 24:3150, Singapore: SEAMEO-RELC.

Long MH 1991. Focus on Form: A Design Feature in Language Teaching Methodology. In de Bot, K., Ginsberg, R., and Kramsch, C. (Eds.), Foreign Language Research in Cross-cultural Perspective. Amsterdam: John Benjamins.
Long, M.H., Adams, L., McLean, M., and Castanos, F. 1976. Doing Things with Words: Verbal Interaction in Lockstep and Small Group Classroom Situations. In Crymes, R, and Fanselow, J. (Eds.), On TESOL '76. Washington, D.C.: TESOL.

Long, M.H. and Crookes, G. 1992. Three Approaches to Task-based Syllabus Design. TESOL Quarterly, 26(1):27-56.

Nunan, D. 1989. Designing Tasks for the Communicative Classroom. Cambridge: Cambridge University Press.

Nunan, D. 1991. Communicative Tasks and the Language Curriculum. TESOL Quarterly, 25(2):279-295.

Pica, T., Holliday, L., Lewis, N., Berducci, D., and Newman, J. 1990. Variation in NS-NNS Negotiated Interaction: Differential Contributions of Interlocutor Gender and Information Control, Paper presented at Second Language Research Forum, Eugene, Oregon, 1989. In Proceedings of SLRF 1990 Forum.

Pica, T., Kanagy, R., and Falodun, J. 1993. Choosing and Using Communication Tasks for Second Language Instruction and Research. In Crookes, G. and Gass, S.M. (Eds.), Tasks and Language Learning: Integrating Theory and Practice. Clevedon: Multilingual Matters.

Pica, T., Young, R., and Doughty, C. 1987. The Impact of Interaction on Comprehension. TESOL Quarterly, 21(4):737-758.

Prabhu, N.S. 1984. Procedural Syllabuses. In Read, J.A.S. (Ed.), Trends in Language Syllabus Design, Anthology Series 13:272-280. Singapore: Singapore University Press for SEAMEO-RELC

Richards, J., Platt, J., and Weber, H. 1985. Longman Dictionary of Applied Linguistics. London: Longman.

Richards, J.C. and Rodgers, T.S. 1986. Approaches and Methods in Language Teaching. Cambridge: Cambridge University Press.

Rodgers, T.S. 1990. After Methods, What? In Anivan, S. (Ed.), Language Teaching Methodology for the Nineties, Anthology Series 24:1-21. Singapore: Singapore University Press for SEAMEO-RELC.

Savignon, S. 1991. Communicative Language Teaching: State of the Art. TESOL Quarierly, 25(2):261-277.

Wright, T. 1987. Instructional Task and Discoursal Outcome in the L2 Classroom. In Candlin, C.N. and Murphy, D. (Eds.), Language Leaming Tasks (Lancaster Practical Papers in English Language Education) 7: 47-68. Englewood Cliffs, N.J.: Prentice Hall 